\title{
Outperforming markets: IC and the long- term performance of Japanese IPOs
}

Article

Accepted Version

Creative Commons: Attribution-Noncommercial-No Derivative Works 4.0

Nielsen, C., Rimmel, G. and Yosano, T. (2015) Outperforming markets: IC and the long-term performance of Japanese IPOs. Accounting Forum, 39 (2). pp. 83-96. ISSN 0155-9982 doi: https://doi.org/10.1016/j.accfor.2015.04.001 Available at https://centaur.reading.ac.uk/73606/

It is advisable to refer to the publisher's version if you intend to cite from the work. See Guidance on citing.

To link to this article DOI: http://dx.doi.org/10.1016/j.accfor.2015.04.001

Publisher: Elsevier

All outputs in CentAUR are protected by Intellectual Property Rights law, including copyright law. Copyright and IPR is retained by the creators or other copyright holders. Terms and conditions for use of this material are defined in the End User Agreement.

\section{www.reading.ac.uk/centaur}

\section{CentAUR}

Central Archive at the University of Reading

Reading's research outputs online 


\title{
Outperforming markets: IC and the long-term performance of Japanese
}

\section{IPOs}

\author{
Christian Nielsen ${ }^{\mathrm{a}, *}$, Gunnar Rimmel ${ }^{\mathrm{b}, \mathrm{c}}$, Tadanori Yosano ${ }^{\mathrm{d}, 1}$ \\ ${ }^{a}$ Aalborg University, Fibigerstræde 11-58, DK 9220 Aalborg, Denmark \\ b Jönköping International Business School, P.O. Box 1026, SE-551 11 Jönköping, Sweden \\ c Gothenburg Research Institute, Sweden \\ d Kobe University, Graduate School of Business Administration, Rokkodai 2-1, Nada, Kobe 657-8501, Japan
}

\begin{abstract}
This article studies the effects of disclosure practices of Japanese IPO prospectuses on long- term stock performance and bid-ask spread, as a proxy for cost of capital, after a company is admitted to the stock exchange. A disclosure index methodology is applied to 120 IPO prospectuses from 2003. Intellectual capital information leads to significantly better long- term performance against a reference portfolio, and is thus important to the capital market. Further, superior disclosure of IC reduces bid-ask spread in the long-term, indicating that such disclosures are important in an IPO setting. Analysts and investors can attain higher long-term returns by understanding IC.
\end{abstract}

Keywords: Voluntary disclosures Intellectual capital IPO prospectuses

Long-term performance Bid-ask spread

Japan

\section{Introduction}

The efficient functioning of capital markets is dependent upon the flow of information between companies and investors, either directly or indirectly through financial intermediaries, such as analysts. Information reduces investors' perceived risk when predicting a company's future performance. Information asymmetry will always be present to some extent given that investors never have access to the same information as the top management team in a company. However, effective information disclosure practices have been shown to be advantageous both from investor and company perspectives.

In the last couple of decades, it has been hypothesized that accounting information is insufficient as standalone informa- tion for investors and analysts seeking to value companies. However, accounting information is still perceived as among the most important information constituents of the total information set. Furthermore, it has been indicated that this insuffi- ciency with accounting information is especially problematic when a company is unknown to the investor, which is the case for companies having not been previously publically traded. The ability to attract capital is vital for many industrial sectors today, and information disclosure can reduce the perceived risk of the investors. Therefore, this article studies disclosures

made during the initial public offering (IPO) phase, when building investors' knowledge of the company is quite an intense process.

Studying voluntary disclosures in IPO prospectuses has a twofold significance. It is not just crucial for academia, but also for stakeholders in the financial markets. First, companies continuously need to pursue enhanced disclosure practices by minimizing, prioritizing, and structuring the corporate information in relation to strategy, value creation, and intellectual capital (IC), as well as environmental, social, and governance factors. This is important because companies are constantly competing for attention in a global information environment by addressing a multitude of different stakeholders who will potentially take interest in the message being conveyed. Second, an enhanced understanding of which types of voluntary information disclosure facilitate the valuation processes will positively affect the functioning of the capital markets by increasing transparency and decreasing information asymmetry (Jenkinson \& Ljungquist, 2001). Many corporate intellectual capital disclosures are voluntary as mandatory measurement and recognition of intangible assets is limited (e.g. Eckstein, 2004; El-Tawy \& Tollington, 2013; Zéghal \& Maaloul, 2011).

Jenkinson and Ljungquist's (2001) study was among the first that illustrated how lower information asymmetry through improved disclosure practices became proxies for reducing ex ante uncertainty. Other seminal studies illustrate that there exist a number of other metrics which may affect the stock price performance of new listings, for example, retained ownership (Jog \& McConomy, 2003), differences in institutional and legal environments (Hopp \& Dreher, 2013), disclosure of earnings forecasts in IPO prospectuses (Clarkson \& Merkley, 1994), and underwriter reputation (Megginson \& Weiss, 1991). However, these factors have been left outside the scope of this paper as we focus on the effects of disclosing intellectual capital information on information asymmetries.

Schrand and Verrechia (2004) argue that information asymmetry between corporate management and the financial markets at the time of the IPO lead to higher costs of capital. They argue that companies can directly apply voluntary disclosure as a tool to reduce these costs. Further, they find disclosure to be negatively associated with bid-ask spread as a 
proxy for a company's cost of capital. In light of Schrand and Verrechia's (2004) findings, this study therefore examines the long-term stock price performance effects of intellectual capital disclosures.

Voluntary disclosure practices in Japanese annual reports were studied meticulously at a time when Japanese industrial practices were forefront in production management (e.g. Cooke, 1991). However, Japan's leadership in knowledge management and intellectual capital seems to have been caught up with by the rest of the industrialized world in the last $15-20$ years, a development much aligned with the leading stock market index, the Nikkei. The timing of the dataset corresponds with a rising focus of the Japanese government on managing knowledge and intellectual capital. Under the auspices of the Japanese Ministry of Economy, Trade and Industry (METI), the "Intellectual Asset-based Management" (IAbM) guidelines were developed in October 2005. Additionally, METI started to play a central role in the World Intellectual Capital Initiative.

Although Japan has historically been strongly associated with a knowledge-society, Japanese studies focusing on the importance of voluntary disclosure for the capital market are scarce. Aspects of Japanese IPO performance have previously been examined by Dawson and Hiraki (1985), Pettway and Kaneko (1996), and more recently, by Pettway, Thosar, and Walker (2008). To the authors' knowledge, only one previous paper has examined the informational effects of the voluntary disclosures included in Japanese IPO prospectuses (Rimmel, Nielsen, \& Yosano, 2009). The contribution of this study is the examination of the effects of voluntary intellectual capital disclosures on the stock price subsequent to their introduction on the stock exchange, as well as on the companies' cost-of-capital. This is accomplished by analyzing the information content of 120 IPO prospectuses of companies going public on the Nikkei Stock Exchange in 2003. In the methodology section, arguments are given for the appropriateness of precisely this data-point.

There are some limitations to the findings of this study, as the data presented only reflects a 1-year sample of Initial Public Offerings on the Nikkei Stock Exchange. Hence, the results must be read with some caution. Furthermore, it might have been problematic if the Japanese stock market environment in 2003 did not reflect that of a normal "over the business cycle" year. However, this year has been chosen specifically to overcome such problems. Further words of caution for our conclusions lie in the applied auctioning methods within the IPO market. In 2001, book building ${ }^{1}$ was the method applied considerably more than other possible auction methods for IPOs in Japan. Consequently, market participants may have acted differently than they would have otherwise or acted still in accordance with traditional behavior.

The remainder of the paper is structured as follows. Section 2 describes the theoretical foundations of the study and leads to the formulation of the hypotheses concerning IPOs underpricing and cost of capital measured as bid-ask spread in stock across time. In Section 3, the applied research methods are explained, while Section 4 contains the results of the analysis. Finally, the discussion and concluding remarks are contained in Section 5.

\section{Disclosure effects on initial valuation and cost of capital}

The seminal literature advises us that voluntary disclosures are expected to lower the cost of equity capital (see Verrecchia, 2001) because increased disclosure reduces information asymmetry and tends to enhance stock market liquidity by

increasing the demand for a company's stocks (Botosan, 1997; Diamond \& Verrecchia, 1991). This, in turn, may facilitate a more precise valuation of the company. Both Botosan (1997) and Richardson and Welker (2001) confirm that the quantity and quality of disclosure is negatively related to the cost of equity capital for companies.

The more recent academic literature is rich with contributions on IPO valuation (cf. Vance \& Mascarenhas, 2014) examining IPOs long-term performance in relation to industrial sectors (Akhigbe, Johnston, \& Madura, 2006) or institutional and legal environments (Hopp \& Dreher, 2013). In Asia, the Chinese (cf. Kao, Wu, \& Yang, 2009) and Japanese (cf. Kutsuna, Okamura, \& Cowling, 2002; Nagata \& Rhee, 2009; Yamamoto, 2009) stock markets especially have recently been under scrutiny with regard to the performance-related characteristics of IPOs; also, the Malaysian (Too \& Somasundaram, 2011; See \& Rashid, 2012), Taiwanese (Chang, 2011) and Singaporean markets (Singh \& Van der Zahn, 2007, 2008) have been studied. By examining characteristics of intellectual capital disclosures, a specific stream of research has studied how the informativeness of the IPO prospectus affects pricing of the IPOs (e.g. Bukh, Nielsen, Mouritsen, \& Gormsen, 2005; Cordazzo, 2007; Cordazzo \& Vergauwen, 2012; Xu \& Xu, 2012) as well as on general information disclosure in the prospectus (Ström, 2006). In an Asian setting, Singh and Van der Zahn (2007) found a positive association between underpricing and the extent of intellectual capital disclosures in Singaporean IPO prospectuses.

In the wake of this specific stream of literature, the present study focuses on the performance-related effects of voluntary disclosure levels of intellectual capital in Japanese IPO prospectuses; thus, there lies a practical contribution in examining whether certain types of information help Japanese investors in selecting the stocks with the best possible long-term performance. Subsequently, a discussion outlines aspects of long-term performance and bid-ask spread in relation to voluntary disclosure in IPOs to develop this study's hypothesis.

\subsection{Long-term performance of the stock}

A substantial body of research conducted from an information-economics perspective has concentrated on studying why companies disclose more information than is required by regulation (cf. Jenkinson \& Ljungquist, 2001).

Long-term performance of IPOs has been the subject of much research in recent years (see for example, Thomadakis, Nounis, \& Gounopoulos 2012). A thorough review of this literature can be found in Ritter (1991), who also finds evidence that IPOs substantially underperform a sample of matching firms from the closing price on the first day of public trading to their 3-year anniversaries (about 29\% in the three year period after their launch). Most long-term performance studies of IPOs have been conducted in the US and generally companies underperform the market benchmarks. For example, Rajan and Servaes (1997) showed that in the long-term, IPOs underperformed the market by between 17 and $47 \%$. Additionally, Carter, Dark, and Singh (1998) showed that US firms underperformed the market by $19.9 \%$. In the UK, Khurshed, Mudambi, 
and Goergen (1999) documented long-term underperformance of $17.8 \%$ using IPOs on the London Main Market from 1991 to 1995.

Although US and UK studies reveal strikingly similar results, Khurshed et al. (1999) provide a brief review of the field, indicating that there are differences across countries. The degree of under-performance was found to be highest in Australia, namely 51.0\% (Lee, Taylor, \& Walter, 1994), while Brazil follows with 47.0\% (Aggarwal, Leal, \& Hernandez, 1993). Although underperformance seems to be the norm, some exceptions do exist. Country specific studies in Korea by Kim, Krinsky, and Lee (1995) and Sweden by Loughran, Ritter, and Rydqvist (1994) has shown that IPO companies outperformed the market by $91.6 \%$ and $1.2 \%$, respectively. Therefore, it is interesting to study this in the Japanese context, as (Rimmel et al., 2009 ) showed that there is some ambivalence.

Typical explanatory factors of long-term performance include underwriters' reputation (Carter et al., 1998; Michaely \& Shaw, 1994), ownership structure (Jain \& Kini, 1994, 1999, 2000; Kutsuna et al., 2002; Wang, 2004), the pre-IPO performance of a company (Khurshed et al.,1999), degree of multinationality of a company (Khurshed et al., 1999), and industry differences (Ahmad Zaluki, Campbell, \& Goodacre, 2009).

In relation to this study's focus on intellectual capital disclosure in IPO prospectuses, Bessler and Bittelmeyer (2008) find that innovation, patents, and intellectual capital are important factors that have a positive impact on the valuation and on the long-run financial performance of especially young technology firms. Guo, Lev, and Zhou (2004) find similar evidence; R\&D-intensity is positively related to both long-term performance and underpricing. There exist a multitude of studies concerning the value relevance of innovations and patents (cf. Hirschey \& Richardson, 2004; Joshi, Singh Ubha, \& Sidhu, 2012; Lin, Huang, Du, \& Lin, 2012).

For that reason, it can be expected that companies who disclose substantial amounts of information on intellectual capital will be associated with better transparency and therefore also better long-term performance. The hypothesis is divided into an $a$ and a $b$ version. The $a$ version of the hypothesis concerns the total extent of voluntary disclosure captured by applying the disclosure index. The $b$ version concerns the nature of the voluntary disclosure captured by our disclosure index in the sense that it looks at differences according to the specific types of information that is disclosed

H1a. The extent of voluntary disclosure in the IPO prospectus is positively associated with the long-term performance of the stock price

H1b. The nature of voluntary disclosure in the IPO prospectus affects the long-term performance of the stock price equally

\subsection{Bid-ask spread as a proxy for the cost of capital}

The previous section outlined that good disclosure practices leading up to the IPO is expected to affect investors' perceptions of the stock price value. This is because good disclosure practices reduce information asymmetry between company management and the investors (e.g. Joshi et al., 2012; Lin et al., 2012). Coller and Yohn (1997) conclude that better corporate disclosure leads to lower information asymmetry, which in turn reduces the ex-ante uncertainty, and thus both underpricing and bid-ask spreads as a result. Such good disclosure practices with positive results on reducing information asymmetry may relate to the amount of information contained in the IPO prospectus (Cordazzo, 2007), the inclusion of voluntary information on risk factors (Beatty \& Ritter, 1986), R\&D information (La Rosa \& Liberatore, 2014), or management forecasts (Jog \& McConomy, 2003).

Adverse selection theory states that information asymmetry between company management and the capital market manifests itself in the form of reduced liquidity in relation to the company's stocks (see Michaely and Shaw (1994) for a thorough review of adverse selection models). The effect of this would be that in order to convince investors to buy stocks in firms with lower levels of liquidity, the companies will be forced to release stocks with a discount, thereby creating a higher cost of capital. According to Diamond and Verrecchia (1991), the company can reduce its cost of capital by increasing the amount of information disclosed because this will increase interest in the stock and thereby also its liquidity. The bid-ask spread is a measure of liquidity companies' shares and is in this study applied to examine the relationship between cost-of-capital and disclosure levels.

There are a number of studies that attempt to link disclosure levels to cost of capital. Welker (1995), for example, concludes that disclosure levels reduce information asymmetry and increase stock liquidity. Botosan (1997) expands this result by establishing that the above relationship between disclosure level and cost of capital is especially present for companies with infrequent analyst following. Leuz and Verrechia (2000) indicate similar conclusions. Although, applying bid-ask spreads as a proxy for cost-of-capital may not be as clean a measure as underpricing (Schrand \& Verrechia, 2004). Therefore, this study applied this variable since its strength is related to illustrating developments in information asymmetry over time.

For that reason, it can be expected that companies disclosing substantial amounts of information on intellectual capital will be associated with better transparency and therefore also lower bid-ask spreads. The hypothesis is divided into an $a$ and a $b$ version. The $a$ version of the hypothesis concerns the total extent of voluntary disclosure captured by applying the disclosure index. The $b$ version concerns the nature of the voluntary disclosure captured by our disclosure index in the sense that it looks at differences according to the specific types of information that is disclosed:

H2a. The extent of voluntary disclosure in the IPO prospectus is inversely associated with the bid-ask spread

H2b. The nature of voluntary disclosure in the IPO prospectus affects the bid-ask spread equally

The next section describes the construction of the disclosure index and the statistical tests applied to analyze the data.

\section{Research method}


There is an extensive amount of accounting literature concerned with providing frameworks for the study of the nature and extent of corporate disclosure (cf. Adrem, 1999; Cooke, 1989; Rimmel, 2003, 2004). The most frequently applied frameworks divide corporate disclosures into the categories of mandatory disclosure studies (Wallace, Naser, \& Mora, 1994), voluntary disclosure studies (Gray, Meek, \& Roberts, 1995; Guthrie \& Petty, 2000; Hossain, Tan, \& Adams, 1994), and disclosure studies that consider both mandatory and voluntary disclosure items (Beattie, McInnes, \& Fearnley, 2004; Inchausti, 1997). Rather than considering whether a piece of information is mandatory or not, the present study focuses on the effect of all the types of information contained in the narrative sections of the IPO prospectus, in turn arguing that the value and relevance of information must be seen from the user's perspective.

\subsection{The disclosure index}

This study applies a disclosure index for the quantification of information levels disclosed in IPO prospectuses. Following a common path of previous disclosure index studies, this study conducts a replication of the disclosure index used in a number of recent disclosure studies of IPO prospectuses by Bukh et al. (2005) in relation to Danish IPO prospectuses, Italian IPO prospectuses (Cordazzo, 2007), Japanese IPO prospectuses (Rimmel et al., 2009), and Singaporean IPO prospectuses (Singh \& Van der Zahn, 2007).

The particular research design was chosen for our study because the application of the disclosure index approach on an IPO prospectus represents a proxy for the quality of the information level that the company supplies to the capital market in connection with the IPO (Bukh et al., 2005). When applying such an approach, it is, however, important to consider the reliability of the results and the objectivity of the study (Unerman, 2000).

In the present study, these criteria are handled through a thorough literature review of underpricing and bid-ask spread studies, clear instructions in the coding process, and verifying the coding through separate coding by multiple researchers (cf. Beattie et al., 2004; Clatworthy \& Jones, 2006; Jones, 1994). Beattie et al. (2004) argue that the amount of disclosure might not be an exact indicator of disclosure quality. The disclosure level may also be affected by factors such as the CEO's ability to communicate clearly or the choice of accounting principles. However, as this study is concerned with the effects of, the extent, and the nature of IPO prospectus disclosures, the disclosure index methodology fulfills the study's requirements satisfactorily.

There are no widely accepted theoretical guidelines for selecting the items that make up a disclosure index (Beattie et al., 2004). Therefore, the successful use of the disclosure index methodology depends on critical and cautious selection of items (Marston \& Shrives, 1991). According to Bukh et al. (2005) the choice of items in the applied disclosure index of this study was based on a thorough inspection of the literature on corporate disclosure (cf. AICPA, 1994; Beattie and Pratt, 2002; Eccles \& Mavrinac, 1995) and intellectual capital reporting (Guthrie \& Petty, 2000; Mouritsen et al., 2003; Sveiby, 1997). Regarding intellectual capital statements, the experiences and results of a major Danish project concerning intellectual capital statements (Mouritsen et al., 2003) were a major source of insight.

In this study of the extent of disclosure of non-accounting information - e.g. information on knowledge-based resources, strategy and processes - in Japanese IPO prospectuses, a disclosure index consisting of 78 items divided into 6 different categories was applied. All of the items in the disclosure index are listed in Appendix A. The descriptive statistics on the item-level of the disclosure index is not discussed further in this paper.

The contents of each IPO prospectus were compared to the items on the disclosure scoreboard and coded as 1 or 0 , depending upon whether the IPO prospectus contained or did not contain the voluntary disclosure. Accordingly, the extent of disclosure was quantified as the percentage of recorded information items found in the prospectus. This can be seen in the following formula, which was used to calculate the index score of each IPO prospectus:

$$
\operatorname{DISC}_{i}=\quad \begin{array}{ll}
{ }^{m} \underline{d}_{i} & \\
& M
\end{array} \quad \times 100 \%
$$


where $d_{i}$ expresses item $i$ with the value found in the IPO prospectus in question, otherwise $0 . M$ expresses the maximum of information disclosed in the IPO, which could be 78 items. The analysis of the disclosure scoreboard for this study is additive and unweighted, following the path of the studies conducted by Adrem (1999), Meek, Roberts, and Gray (1995), and Cooke (1989). All three studies referred to Spero's (1979) empirical findings that weighting of information is not relevant for several reasons. The most important one is to decrease subjectivity, which would be the case if applying special weights for different items, as the user's preferences are unknown. Hence, either a company discloses a voluntary item in its IPO prospectus or not, which shows that the number of items measures the amount of disclosure. No ranking list for the importance of different items is applied, nor is the number of words about an item used. This procedure is corroborated by the criticisms discussed in the study by Hackston and Milne (1996).

\subsection{Data sample and descriptivestatistics}

Based on a series of previous studies, for the purpose of this study, the effects of disclosure on long-term performance serve as a proxy for information asymmetry and bid-ask spread serves as a proxy for cost of capital. Data from Professor Jay Ritter ${ }^{2}$ illustrates that there is a marked difference between the general underpricing levels of Japanese IPOs in the period prior to the late 1980s and then the period after the late 1980s in relation to the amount of companies going public. From this study's dataset, it was thus decided to focus on 2003 because of the following aspects:

(1) 2003 had been unaffected by the Japanese Guideline for Intellectual Property Information Disclosure (GIPID), which had ambitious aspirations to shape future IC reporting by Japanese corporations by higher disclosure requirements on IC items (Johanson, Koga, Skoog, \& Henningsson, 2006). As a consequence, the level of disclosing voluntary IC information in Japanese IPOs would have been affected in the years when the GIPID was established, in the years after 2003.

(2) 2003 was a normal year according to the business cycle and was not affected by the dot-com bubble, nor were there any economic crisis effects in thatyear.

(3) 2003 represents a normal sample in relation to the amount of IPOs. ${ }^{3}$

(4) Finally, 2003 represents a normal year in respect to the level of underpricing. ${ }^{4}$

The data for this study consists of all IPO prospectuses from stock exchange listings at the Nikkei Stock Exchange in the period 1 January 2003 to 31 December 2003. The 120 IPO prospectuses analyzed were obtained from EDGAR Online systems. Prospectuses disclosed in connection with capital increases, cross-listing arrangements, and companies issuing preferred shares only were excluded as well as stock index funds, life investment funds, and real estate unit funds. The sample of IPOs is dispersed across a range of industrial classifications. Table 1 classifies the number of IPO prospectuses available for analysis by industry category. The table, for example, illustrates that technology companies comprise $30.83 \%$ of the sample, while consumer goods companies comprise $33.33 \%$ of the sample, and so forth.

Table 1

\begin{tabular}{|c|c|c|c|}
\hline Six-sector breakdown & Nikkei industrial classification & $N$ & $\begin{array}{l}\text { Percentage of } \\
\text { sample }(\%)\end{array}$ \\
\hline Technology & $\begin{array}{l}\text { Pharmaceuticals, electric machinery, automobiles \& auto parts, precision } \\
\text { instruments, communications }\end{array}$ & 37 & 30.83 \\
\hline Financials & Banking, other financial services, securities, insurance & 4 & 3.33 \\
\hline Consumer goods & Fishery, foods, retail, services & 40 & 33.33 \\
\hline Materials & $\begin{array}{l}\text { Mining, textiles \& apparel, pulp \& paper, chemicals, petroleum, rubber, glass \& } \\
\text { ceramics, steel, non-ferrous metals, trading companies }\end{array}$ & 17 & 14.17 \\
\hline Capitalgoods/others & $\begin{array}{l}\text { Construction, machinery, shipbuilding, transportation equipment, other } \\
\text { manufacturing, real estate }\end{array}$ & 21 & 17.50 \\
\hline Transportation/utilities & Railway \& bus, land transport, marine transport, air transport, warehousing, & 1 & 0.83 \\
\hline
\end{tabular}


Table 2

Number of companies in each disclosure group.

\begin{tabular}{lcccrrrr}
\hline Type & Total & Employee & Customer & IT & Processes & R\&D & Strategic statements \\
\hline Low disclosure & 42 & 43 & 53 & - & 85 & 91 & 56 \\
Medium disclosure & 47 & 50 & 67 & - & - & 43 \\
High disclosure & 31 & 27 & 120 & 120 & 29 & 14 & 23 \\
Total sample & 120 & 120 & 120 & 54 & 120 \\
\hline
\end{tabular}

Table 3

Descriptive statistics of overall disclosure.

\begin{tabular}{|c|c|c|c|c|c|c|c|c|c|c|c|c|c|}
\hline \multirow[t]{2}{*}{ Type } & \multicolumn{4}{|l|}{ Total } & \multicolumn{5}{|c|}{ Employee } & \multicolumn{4}{|c|}{ Customer } \\
\hline & Mean & \multicolumn{2}{|c|}{ Median } & $\begin{array}{l}\text { Standard } \\
\text { deviation }\end{array}$ & \multicolumn{2}{|c|}{ Mean } & \multicolumn{2}{|c|}{ Median } & $\begin{array}{l}\text { Standard } \\
\text { deviation }\end{array}$ & Mean & \multicolumn{2}{|c|}{ Median } & $\begin{array}{l}\text { Standard } \\
\text { deviation }\end{array}$ \\
\hline Low disclosure & 8.95 & 9 & & 2.84 & 1.23 & & 1 & & 0.68 & 0.81 & 1 & & 0.39 \\
\hline Medium disclosure & 17.34 & 17 & & 2.61 & 3.34 & & 3 & & 0.48 & - & - & & - \\
\hline High disclosure & 28.19 & 27 & & 5.61 & 5.70 & & 5 & & 0.95 & 2.79 & 2 & & 1.05 \\
\hline \multirow[t]{2}{*}{ Type } & \multicolumn{3}{|l|}{ IT } & \multicolumn{2}{|c|}{ Processes } & \multicolumn{4}{|c|}{$R \& D$} & \multicolumn{4}{|c|}{ Strategic statements } \\
\hline & Mean & Median & $\begin{array}{l}\text { Standard } \\
\text { deviation }\end{array}$ & Mean & Median & & $\begin{array}{l}\text { dard } \\
\text { iation }\end{array}$ & Mean & Median & $\begin{array}{l}\text { Standard } \\
\text { deviation }\end{array}$ & Mean & Median & $\begin{array}{l}\text { Standard } \\
\text { deviation }\end{array}$ \\
\hline Low disclosure & 0 & 0 & 0 & 0 & 0 & 0 & & 0 & 0 & 0 & 0.56 & 1.00 & 0.50 \\
\hline Medium disclosure & - & - & - & - & - & - & & 1 & 1 & 0 & 2 & 2 & 0 \\
\hline High disclosure & 1.57 & 1.00 & 0.98 & 1.41 & 1.00 & 0.5 & & 3.44 & 3.00 & 1.40 & 4.13 & 4.00 & 1.10 \\
\hline
\end{tabular}

For the sake of the statistical tests performed below, the dataset was divided into a high, medium, and low disclosure group according to the level of intellectual capital disclosure in the IPO prospectuses. In the overall disclosure category, as well as the sub-indices of Employees, Research and Development, and Strategic Statements, this was achieved by dividing the data according to the identified tertiles. The number of items disclosed in the three sub-indices of Customers, IT, and Processes were generally smaller, and therefore, when testing the disclosure effects it was necessary to divide them into only two groups characterized by high and low disclosure. The identical method of segmentation was applied by using the median values of those three subcategories' items (Table 2).

In Table 3, the descriptive statistics for the population is shown.

\subsection{Statisticalmodel}

In order to answer the hypotheses set out in the theoretical section of this paper, two types of tests were applied to the data. These are described separately in the next two sections concerning long-term performance (Section 3.3.1) and bid-ask spreads (Section 3.3.2).

\subsubsection{Long-term performance}

In Table 4, all the variables applied in the statistical testing of the relationship between disclosure and long-term performance are described in detail.

For the purpose of answering hypotheses $\mathrm{H} 1 \mathrm{a}$ and $\mathrm{H} 1 \mathrm{~b}$, a two-sample $t$-test with unequal variances for the total index (extent; hypothesis H1a) and for each sub-index (nature; hypothesis H1b) was applied. Testing for underpricing required measuring the 3-year stock-price performance variance between high and low disclosure level firms. For the analysis, there was an initial choice between calculating the abnormal long-term stock performance by using both the standard market model and the reference portfolio model. In the standard market model, the excess long-term stock returns would

Table 4

Summary variables for long term performance and their proxy measure determination.

\begin{tabular}{ll}
\hline Variable & Description \\
\hline $\mathrm{LTP}_{i}$ & Difference between the initial offering price and the closing price on the day of the 3-year anniversary for firm \\
& $i$, expressed as a percentage of the initial offering price \\
$\mathrm{DISC}_{i}$ & The total disclosure of firm $i$, expressed as a percentage of the total disclosure index \\
$\mathrm{CARRP}_{i}$ & Cumulative average returns, reference portfolio \\
\hline
\end{tabular}

Table 5

Summary variables for bid-ask spread and their proxy measure determination.

\begin{tabular}{ll}
\hline Variable & Description \\
\hline DISC $_{i}$ & The total disclosure of firm $i$, expressed as a percentage of the total disclosure index \\
BAS1YRAVG $_{i}$ & The 1-year average bid-ask spread \\
\hline
\end{tabular}

Table 6

Results of cumulative average returns to reference portfolio. 


\begin{tabular}{llcll}
\hline & $\begin{array}{l}\text { Average low } \\
\text { disclosure group (\%) }\end{array}$ & $\begin{array}{l}\text { Average high } \\
\text { disclosure group (\%) }\end{array}$ & Significance & Comments \\
\hline Total index & 28.78 & 99.15 & $\operatorname{Pr}(T<t)=0.0072$ & Very significant and a positive relation \\
Employees & 29.68 & 111.24 & $\operatorname{Pr}(T<t)=0.0038$ & Very significant and a positive relation \\
Customers & 78.66 & 63.07 & $\operatorname{Pr}(T<t)=0.5065$ & No difference, slightly opposite sign \\
IT & 63.67 & 85.91 & $\operatorname{Pr}(T<t)=0.4238$ & No difference, slightly positive sign \\
Processes & 67.67 & 77.99 & $\operatorname{Pr}(T<t)=0.7390$ & No difference, slightly positive sign \\
R\&D & 90.70 & 45.38 & $\operatorname{Pr}(T<t)=0.0332$ & Significant and opposite sign than expected \\
Strategic statements & 82.75 & 60.85 & $\operatorname{Pr}(T<t)=0.4302$ & No difference, slightly opposite sign \\
\hline
\end{tabular}

be compared against the Tokyo Stock Price Index, commonly known as TOPIX, which tracks all domestic companies of the exchange's First Section and in the reference portfolio model, the excess long-term stock returns would be compared against a reference portfolio.

Studies by Barber and Lyon (1997) or Kothari and Warner (1997) have previously indicated that the cumulative abnormal return (CAR) compared against market performance may result in misspecification. This problem implies that the statistical Type I error is more likely, or that the null hypothesis (that the abnormal return equals zero) is rejected more frequently by chance alone. In Japan, previous research has also indicated that using the abnormal return (AR) with the TOPIX benchmark often has a positive bias. Hence, it was chosen to calculate AR against the mean return of the reference portfolio in order to avoid misspecification problems. This reference portfolio is based on two major risk factors found in the stock samples, namely book-to-market ratio and firm size. The procedures employed in the construction of the reference portfolio are as follows:

(a) First, all stocks that were listed during the same month of each IPO occurring were identified. These stocks were divided into five groups based on firm size to define the boundaries of each quintile.

(b) Within each quintile, the stocks were further sorted into five groups based on the book-to-market ratio to define the boundaries of the inner quintile, creating 25 cells. Each IPO firm's stock performance was compared to the average stock performance of firms in its corresponding cell, yielding its abnormal return.

\subsubsection{Bid-ask spread}

In order to answer hypotheses $\mathrm{H} 2 \mathrm{a}$ and $\mathrm{H} 2 \mathrm{~b}$, a two-sample $t$-test was applied with unequal variances for the total index (extent; hypothesis H2a) and for each sub-index (nature; hypothesis H2b). In testing for bid-ask spread, we measured 1- year average, closing bid-ask stock-price contrast between high and low disclosure level firms, after the IPO as depicted in Section 3.2.

The bid-ask spread is calculated with the following formula:

Bid-ask spread $=($ closing bid price $\quad$ closing ask price $) /$ closing stock price

In Table 5, all the variables applied in the statistical testing of the relationship between disclosure and bid-ask spreads and their specific determination are described in detail.

\section{Results}

\subsection{Long-term performance}

Table 6 shows the 3-year abnormal return of both high and low total disclosure group as well as the following subcategories: Employees, Customers, IT, Processes, Research and Development, and Strategic Statements. In regards to total disclosure level, the 3-year abnormal return of the high disclosure group is $99.15 \%$, which is larger than that of the low

Table 7

Results of 1-year average bid-ask spread.

\begin{tabular}{lllll}
\hline & $\begin{array}{l}\text { Average low } \\
\text { disclosure group (\%) }\end{array}$ & $\begin{array}{l}\text { Average high } \\
\text { disclosure group (\%) }\end{array}$ & Significance & Comments \\
\hline Total index & 1.726 & 1.370 & $\operatorname{Pr}(T<t)=0.0603$ & Very significant and a positive relation \\
Employees & 1.702 & 1.436 & $\operatorname{Pr}(T<t)=0.1882$ & No difference, slightly positive sign \\
Customers & 1.641 & 1.341 & $\operatorname{Pr}(T<t)=0.0259$ & Very significant and a positive relation \\
IT & 1.500 & 1.410 & $\operatorname{Pr}(T<t)=0.5638$ & No difference, slightly positive sign \\
Processes & 1.473 & 1.476 & $\operatorname{Pr}(T<t)=0.9888$ & No difference, slightly opposite sign \\
R\&D & 1.486 & 1.363 & $\operatorname{Pr}(T<t)=0.3493$ & No difference, slightly positive sign \\
Strategic statements & 1.564 & 1.475 & $\operatorname{Pr}(T<t)=0.5574$ & No difference, slightly positive sign \\
\hline
\end{tabular}

disclosure group that is equivalent to $28.78 \%$, at a $5 \%$ significance level. This result supports the H1a, which addresses that the extent of voluntary disclosure level is positively associated with the long-term performance of the stock.

In regard to the subcategory of Employees, the 3-year abnormal return of high disclosure group of $111.24 \%$ is greater than that of the low disclosure group, at $29.68 \%$, with a $1 \%$ significance level. For the subcategories IT and Process, the 3-year abnormal return of high disclosure group, at $85.91 \%$ and $77.99 \%$, is insignificantly greater than that of the low disclosure group of $63.67 \%$ and $67.67 \%$, respectively. However, in regards to the subcategory Research and Development, the 3-year abnormal return of high disclosure group $45.38 \%$ is smaller than that of low disclosure group $90.70 \%$, with a $10 \%$ significance level. Additionally, for subcategories Customers and Strategic Statements, the 3-year abnormal return of high disclosure group $63.07 \%$ and $60.85 \%$ is insignificantly smaller than that of low disclosure group $78.66 \%$ and $82.75 \%$. Therefore, the results for 
the subcategories Employees, IT, and Processes mean that H1b must be rejected. From the result of the total disclosure level, it can be concluded that employee related disclosures are the key factor of predicting the long-term performance of IPOs.

\subsection{Bid-ask spread}

Table 7 shows the 1-year average bid-ask spread of both the high and low total-disclosure groups, as well as the following subcategories: Employees, Customers, IT, Processes, Research and Development, and StrategicStatements. In regards to total disclosure level, the 1-year average bid-ask spread of high disclosure group 1.370\% is smaller than that of low disclosure group $1.726 \%$, with a $10 \%$ significant level. This result supports the H2a, which addresses that the extent of voluntary disclosure level is inversely associated with the bid-ask spread.

In regards to the subcategory of Customers, the 1-year average bid-ask spread of the high disclosure group is calculated to $1.341 \%$, and this is significantly smaller than that of low disclosure group: $1.642 \%$, on a $5 \%$ significance level. For the subcategories of Employees, IT, Research and Development, and Strategic Statements, the 1-year average bid-ask spread of the high disclosure group, $1.436 \%, 1.409 \%, 1.363 \%$ and $1.475 \%$, is insignificantly smaller than those of low disclosure group, $1.701 \%$, $1.500 \%, 1.486 \%$ and $1.564 \%$,respectively. However, in regards to thesubcategory Processes, the 1 -yearaverage bid-ask spread of high disclosure group's $1.476 \%$ is insignificantly greater than that of low disclosure group's $1.473 \%$. Therefore, it can be concluded that the results for the subcategories, Customers (significant) and Employees and IT (insignificant), imply that $\mathrm{H} 2 \mathrm{~b}$ must be rejected. Together with the result of the total disclosure level, it is possible to conclude that customer-related disclosures are a key factor for reducing the information asymmetry problem surrounding IPOs.

\section{Discussion of the results}

In the literature, there has historically been some disagreement as to the relationship between disclosure levels and their effects on the performance of IPOs. While Loughran and Ritter (2004) argue that higher disclosure levels lead to poorer stock price performance for IPOs, Schrand and Verrechia (2004) demonstrate that the opposite is true, namely that greater disclosure frequency in the period prior to the IPO is associated with a lower cost of capital in the form of lower bid-ask spreads and lower analyst forecast dispersion. The focus in this paper is not as much concerned with the effects of voluntary disclosures on the short-term characteristics of IPOs, like underpricing for example. This study's focus is on the value of a set of information that is concerned with the long-term value creation and financial sustainability of a company, namely the intellectual capital. As such, this paper is concerned with understanding how to facilitate the capital market in selecting the best stocks for the long-term, using long-term oriented data.

\subsection{Discussion of long-term performance results}

Intellectual capital was found to have a significant effect on the long-term stock price performance of our IPO population and as such, hypothesis H1a holds. Hence, investing in companies that are transparent about their value creation and softer values including, for example, details about their strategy, business models, human resources, and other parameters of intellectual capital through a more active disclosure policy will lead to a significant over-performance in returns in comparison to those companies that do not.

The analysis also reveals that, with regard to the nature of the disclosures, the employee category is especially the main driver of the significant result of hypothesis H1a. The composure of the disclosures concerning employee-related intellectual capital by the companies that have high disclosure ratios concentrate on aspects such as staff breakdown by department, employee expenses in relation to number of employees, statements of policy on competence development, recruitment policies, remuneration and incentive systems, and finally, dependence on key personnel. Therefore, it can be concluded that the resources described above are central elements of importance for companies in order to execute a long-term strategy. Typically, IPO prospectuses contain a thorough description of strategic direction to reach the main financial goals of the company (cf. Bhabra \& Pettway, 2003; Tokyo Stock Exchange, 2012).

The results imply that companies who disclose the intellectual capital information relating to the employee category thereby signal to the capital market that they have a plan for managing these resources. Thus, this study confirms the conclusions of Sakakibara, Hansson, Yosano, and Kozumi (2010), whose findings confirm that analysts would find this data relevant and be prone to use it if it were provided. This also means that the results of this study are in opposition to the propositions of Healy and Palepu (2001) who suggest that voluntary disclosures such as customer satisfaction and human capital do not carry value by themselves and that only management forecasts as a voluntary item increases the predictability power of stock price returns. Normative researchers such as Healy and Palepu (2001) are missing the point that these types of disclosures concerning employees also play an important role in the creation of accountability of the signals from the management team Murthy and Mouritsen (2011). Furthermore, the findings from this study are also very much in line with the suggestions made by Mouritsen and Larsen (2005) who argue for the importance of creating levers of control on such unstable resources like human capital and competencies. Indicating an understanding of and a plan for managing these types of resources thus signals the ability to over-perform the market.

For analysts and investors, this means that in order to identify stocks that outperform the market, they will need to gain insight into the companies' proposed plans for strategy execution, for example by asking themselves whether the company has the correct composition, alignment, and incentivized human resources to leverage the described strategy. In addition, it is also imperative that the company has the right incentive systems for retaining these human resources and keeping them from moving to competitors. In an acquisition setting, Ranft and Lord (2002) confirm that retention of specific types of human capital is critical for determining success in terms of future performance. More interestingly, 
they stress that soft incentives, such as autonomy, status, and commitment significantly affect retention, but economic incentives do not.

Surprisingly, the results concerning the R\&D category had an opposite sign than what was expected (cf Cho \& Lee, 2013). The analysis revealed a significant difference where the low disclosure group had almost twice the long-term performance than that of the high disclosure group, namely $90.7 \%$ versus $45.8 \%$ in returns. This may indicate that there is a higher risk ascertained to R\&D disclosures, such as statements of policy, strategy, and R\&D objectives, expenses, and investments in product development and design, as well as patents. This is interesting since we initially expected a positive view of activities that have the objective to sustain corporate profitability in the long term. Previous evidence provided by Eberhart, Maxwell, and Siddique (2004) in a non-IPO setting, suggest that increases in R\&D spending are beneficial to investors, although the market is slow at recognizing this information. The alternative explanation in the IPO setting of this article, however, may be that the companies included in this study are revealing too much information in their prospectuses and by doing so, they have pushed too much of this information into the stock price, in turn leaving no room for positive surprises. Conversely, companies that do not reveal too much of this information will be more likely to experience that the information is incorporated into the stock price in a gradual manner, thus increasing stock price returns. The synthesis of this discussion is that if companies only reveal R\&D expenditures, then the market will incorporate them gradually. However, if the company discloses sufficient information for the investors to understand the reasons behind these activities, this information is incorporated into the stock prices straight away.

This reveals that the capital market is very focused and perhaps also very bullish on information such as R\&D spending, R\&D strategy, and patents. It may be speculated that it is in general easier for analysts and investors to understand and relate information on $R \& D$, like, for example, patents and R\&D spending to cash flow predictions than some of the other information categories of the intellectual capital index, such as employee resources, internal processes, and customer loyalty. At the same time, the analysts and investors may be prone to include this information in an uncritical manner. Perhaps they include too large of values into their spreadsheets or are not discounting enough for the risks ascertained to R\&D uncertainties. Faulkner (1996) accentuates this view in his criticism of the use of DCF models for valuing $R \& D$ projects, and concludes that real options theory is a much more appropriate tool for such purposes

\subsection{Discussion of results concerning bid-ask spreads}

Higher disclosure of intellectual capital affects bid-ask spreads positively when measured on the 1-year average of trading. Thus indicating that information on intellectual capital is a significant component for investors when they are assessing information asymmetries. Accordingly, this voluntary information reduces ex ante uncertainty and thereby also the cost of capital of IPO companies. The fact that information on intellectual capital disclosed in the prospectus prior to the IPO has a significant long-term effect on the cost of capital must be explained by the higher transparency of the company. It is interesting that the companies in the high disclosure group are able to sustain this advantage over such a long period. This has two possible explanations. The first one is that it takes time to change the information supply of a company, perhaps because it is strongly rooted in corporate culture, as is vastly suggested in the corporate communications literature. The other explanation is the reputational effect of transparency and that it is difficult to alter the capital market's perception of this, at least in the short term.

Almost all of the subcomponents of the intellectual capital index had the correct sign in the bid-ask analysis. However, it was the customer component that was the main driver of the overall index, as being both positive and significant. The primary types of information disclosed were customer segment information and information on customer intimacy. Customer segment information is important for creating transparency about the strength of the various segments and our findings contradict those of Ali, Klasa, and Yeung (2009) who indicate that companies with strategic competitive advantages attempt to protect their market shares by disclosing less information. This segment information also conveys a more detailed understanding of how the company differentiates its offerings between customer groups, in turn illustrating the company's ability to fine-tune its strategies to fit customer groups. This information is important for investors in estimating how the company will generate revenues in the future and thus also the future cash flow, financial analysts in particular spend time digging into such matters.

Customer intimacy, which here covers aspects such as descriptions of customer relationships, customer involvement, and dependence upon key customers, is also a part of making the analysts and investors feel more secure about the potential future cash flow of the company, in turn reducing the cost of capital. This is because there are strong ties between sustained higher operating profitability and strong customer relationships and organizational structures that support these (cf. Gosman, Kelly, Olsson, \& Warfield, 2004). Interestingly, one component of the customer subcategory was surprisingly not disclosed upon to any extent, namely market share. Market share could be very useful for the capital market, because it is an easy way to estimate future revenues. However, the lack of this information could be due to two factors. First, the IPO companies may have difficulties in projecting their market share going forward as they are entering into a new era with the company. Second, this may be due to reasons of secrecy. Harris (1998) and Ali et al. (2009) confirm this speculation in finding that firms, regardless of the competitive landscape, are reluctant to provide, for example, segment disclosures for the fear of losing both abnormal profits and market share.

\section{Concluding remarks}

In summary, the contribution of this study was to examine the effects of voluntary disclosures on intellectual capital on the long-term performance of the stock price subsequent to the introduction on the stock exchange, as well as the companies' cost-of-capital, estimated through statistical tests on bid-ask spreads. H1a is accepted, and employee-related disclosures 
are found to be a major driver of positive long-term stock price performance. H1b is rejected as the nature of the disclosures affected long-term performance unequally. Interestingly, the subcategory of IC relating to R\&D was significant but posited an opposite sign than was expected. We find support of $\mathrm{H} 2 \mathrm{a}$ indicating that the extent of disclosure in the IPO prospectuses reduces firms' cost of capital. However, H2b must be rejected. Here, customer-related disclosures are found to be a key factor in reducing the information asymmetry problem surrounding IPOs.

Regarding more general contributions relating to IPO valuation and future developments in valuation techniques, the findings discussed above lead us to conclude that voluntary disclosure of intellectual capital (IC) is generally relevant information for investors who wish to assess the probability of the IPO company's long-term performance beating market returns. Vance and Mascarenhas (2014) find evidence of financial metrics that help in constructing superior portfolios of IPO companies, and this study provides further evidence that if the correctly chosen non-financial metrics concerning IC were to be provided additionally, it would clearly be an advantage for investors in their decision-making (see also Ström, 2006).

In regards to the results concerning total disclosure levels, the 3-year abnormal return of the high disclosure group in our sample is $99.15 \%$. This result is significantly larger than the $28.78 \%$ abnormal return of the low disclosure. We found the evidence consistent with the results of Bessler and Bittelmeyer (2008) and Guo et al. (2004). Bessler and Bittelmeyer (2008) find that innovation, patents, and intellectual capital were important factors impacting the valuation and the longterm financial performance of especially young technology firms. Guo et al. (2004) found that R\&D intensity was positively related to both long-term performance of the stock and underpricing.

In conjunction with these results, specifically employee and R\&D-related IC information is found to have relevance for investment decisions. However, this study shows that they are incorporated quite differently into long-term stock prices by investors. Employee-related IC is a key resource for companies in order for them to execute their long-term strategy; therefore, investors gradually evaluate this type of information and whether companies have an understanding and a plan for managing these resources to reach the strategic goal (Mouritsen \& Larsen, 2005). Our results suggest that if a company discloses more information about employees, it creates credibility for its competencies to execute a long-term strategy as this signals the ability to over-perform the market. In this respect, our results do not correlate with a recent study of Chinese IPOs, in which Xu and Xu (2012) find a lack of evidence for a correlation between long-term performance and human capital disclosures. In the other respect, $R \& D$ information is also a core element for companies. However, this type of information helps investors estimate cash flows and to make revenue predictions. Therefore, investors might have pushed too much of this type of information into the stock price in the short term, in turn leaving no room for positive surprises. Eberhart et al. (2004) illustrated that the market is slow at recognizing the extent of beneficial R\&D investment when a company only discloses R\&D cost information. Our findings are consistent with Eberhart et al. (2004) and provide further evidence that if a company discloses more R\&D information, it might help investors estimate R\&D driven cash flow predictions in the short term.

Voluntary IC disclosure generally reduces information asymmetries surrounding IPO and this effect is persistent in the long term. In regards to total disclosure levels, the 1-year bid-ask spread of the high disclosure group is $1.370 \%$. This result is smaller than that of the low disclosure group that is equivalent to $1.726 \%$. This evidence is consistent with the results from Diamond and Verrecchia (1991) and Verrecchia (2001).

Customer-related information is important for investors to estimate how a company will generate revenues in the future. Investors would gain confidence in future revenues if a company discloses information on its major customers, as well as customer involvement and customer relationships. Gosman et al. (2004) showed that the pricing of major customers is consistent with the market recognition of sustainable operating profitability. Our findings are consistent with Gosman et al. (2004) and provide further evidence that if a company discloses more customer-related information, it enhances its transparency and narrows the bid-ask spread in turn lowering the cost of capital in the long run.

In the positioning of this paper, it was argued that the sort of study undertaken here in the Japanese context would provide novel findings. Up against the specific stream of research on the informativeness of the IPO prospectus and the effects of IC disclosures herein (see for example Bukh et al., 2005; Ström, 2006 and Cordazzo, 2007), this study not only expands these studies to a new setting, namely the Japanese capital market, but also advances the statistical models used to test the performance characteristics of the IPO companies in relation to comparably constructed market portfolios.

Wecarefully scrutinized the mostrecentstudies of IPOsin Asian countries to find comparable studies and results. Through this process, we identified a series of studies of IPO prospectus content in some of the smaller Asian capital markets, like Singapore (Singh \& Van der Zahn, 2008), the Malaysian capital market (Rashid, Ibrahim, Othman, \& See, 2012), and the Taiwanese capital market (Chang, 2011). The latter study finds that under conditions of uncertainty concerning the value of a company going public, investors tend to refer to previous admissions to the stock exchange in the same industry, rather than using the information available to them. This might indicate that investors need further guidance or training on how to use non-financial information of the sort studied here. In the context of the Singapore stock exchange, Singh and Van der Zahn (2008) call for regulators to take great care in making such disclosures mandatory because they might impose unnecessary proprietary costs to the market.

Besides these somew hat smaller Asian capital markets, at least when compared to the Japanese market, it seems especially relevant to make a comparison to the Chinese market. However, no studies specifically looking at the effect of disclosure practices or intellectual capital disclosure practices on long-term stock price performance or bid-ask spreads have been identified to date. The closest we get is Yi and Davey's (2010) study of IC in the annual reports of dual-listed companies.

In relation to IPO prospectuses and using Chinese data, Xia, Junyan, and Pei (2013) studied long-term performance on the Chinese A-market. Here, Kao et al. (2009) found that Chinese firms that were going public had lower first-day returns and worse post-IPO stock performance if they made overoptimistic forecasts, while Xu and Xu (2012) discussed the effects of ownership structure in China on IPO performance. This particular interest in ownership structure is also present in several studies of the Japanese stock market providing insight on Japanese institutional structures in the industrial setting 
(Kutsuna et al., 2002; Nagata \& Rhee, 2009; Rimmel et al., 2009) but also in relation to applied methods of auctioning the stocks away to new investors (Kutsuna \& Smith, 2004).

Finally, looking to studies of the Japanese stock markets focusing on the performance related characteristics of IPOs, in Yamamoto's (2009) study of the cost of capital, the characteristics of underpricing looks at whether firms have short or long-term perspectives on their issuances. The only study that truly engages with the relationship between intellectual capital disclosure practices and company characteristics is Rimmel et al. (2009), however, this study falls short of relating the data to long-term performance of the stock price and cost-of-capital issues.

The limitations of the present study are primarily related to the contingencies of disclosure. This study has not correlated differences in IPOs long-term performance to industrial sectors (Akhigbe et al., 2006). Incidentally, Rimmel et al. (2009) did find to be significant in the Japanese context, or discussed the effects of institutional and legal environments (Hopp \& Dreher, 2013) as is the case with some of the recent Japanese and Chinese studies. Further limitations relate to the fact that the IPO prospectuses studied are derived from a single year. However, we have argued for the reasonability of this in the methodology section.

Looking at prospects for future research, it appears potentially advantageous to study this phenomenon over the whole business cycle, to create a longitudinal database. This would enable us to determine whether there is a business cycle effect on the importance of IC for investment decisions and corporate transparency. Also, understanding the importance of IC from the perspective of capital markets is an important element of the ongoing integrated reporting initiatives (cf. IIRC, 2012). Finally, there is a stream of upcoming research on the importance of business models for capital allocation and investment decisions. In order to contribute meaningfully to this field, studies such as the one conducted here would need to include a focus on the profit formula of the company and on how strategic partnerships are leveraged to create value across the value chain.

Appendix A. The disclosure index with corresponding disclosure percentages per item

\begin{tabular}{|c|c|c|c|}
\hline$\%$ of companies making disclosure & & $\%$ of companies making disclosure & \\
\hline Employees (27 items) & 11.7 & IT (5 items) & 10.6 \\
\hline Staff breakdown by age & 0.8 & Description \& reason for investments in IT & 13.8 \\
\hline Staff breakdown by seniority & 0.0 & IT systems & 22.0 \\
\hline Staff breakdown by gender & 0.0 & Software assets & 10.6 \\
\hline Staff breakdown by nationality & 0.0 & Description of IT facilities & 4.9 \\
\hline Staff breakdown by department & 22.0 & IT expenses & 1.6 \\
\hline Staff breakdown by job function & 8.9 & Processes (8 items) & 4.7 \\
\hline Staff breakdown by level of education & 3.3 & & \\
\hline Rate of staff turnover & 1.6 & Efforts related to the working environment & 0.0 \\
\hline Comments on changes in number of employees & 8.1 & Information and communication within the company & 4.1 \\
\hline Staff health and safety & 1.6 & Working from home & 0.0 \\
\hline Education and training expenses/number of employees & 0.0 & Internal sharing of knowledge and information & 14.6 \\
\hline Staff interview & 0.8 & Measure of internal or external failures & 0.0 \\
\hline Statements of policy on competence development & 39.0 & External sharing of knowledge and information & 12.2 \\
\hline Description of competence development program and activities & 14.6 & Fringe benefits and company social programs & 3.3 \\
\hline Education and training expenses & 0.0 & Environmental approvals and statements/policies & 3.3 \\
\hline Absence & 0.0 & Research \& Development (9 items) & 17.6 \\
\hline Employee expenses/number of employees & 67.5 & & \\
\hline Recruitment policies & 53.7 & Statements of policy, strategy and/or objectives of R\&D activities & 47.2 \\
\hline HRM department, division or function & 0.8 & $R \& D$ expenses & 35.0 \\
\hline Job rotation opportunities & 1.6 & R\&D expenses/sales & 2.4 \\
\hline Career opportunities & 2.4 & $R \& D$ invested in basic research & 12.2 \\
\hline Remuneration and incentive systems & 49.6 & R\&D invested in product design/development & 20.3 \\
\hline Pensions & 0.8 & Future prospects regarding R\&D & 7.3 \\
\hline Insurance policies & 2.4 & Details of company patents & 9.8 \\
\hline Statements of dependence on key personnel & 33.3 & Number of patents and licenses, etc. & 10.6 \\
\hline Revenues/employee & 3.3 & Patents pending & 13.8 \\
\hline \multirow[t]{2}{*}{ Value added/employee } & 0.8 & & \\
\hline & & Strategic statements (15 items) & 18.1 \\
\hline Customers (14 items) & 14.2 & Description of new production technology & 35.0 \\
\hline Number of customers & 2.4 & Statements of corporate quality performance & 11.4 \\
\hline Sales breakdown by customer & 24.4 & Strategic alliances & 40.7 \\
\hline Annual sales pr, segment or product & 88.6 & Objectives and reason for strategic alliances & 26.0 \\
\hline Average customer size & 7.3 & Comments on the effects of the strategic alliances & 9.8 \\
\hline Dependence on key customers & 39.8 & Description of the network of suppliers and distributors & 74.8 \\
\hline Description of customer involvement & 6.5 & Statements of image and brand & 23.6 \\
\hline Description of customer relations & 17.1 & Corporate culture statements & 0.8 \\
\hline Education/training of customers & 3.3 & Best practice & 5.7 \\
\hline Customers/employees & 0.8 & Organizational structure & 27.6 \\
\hline Value added pr, customer or segment & 0.8 & Utilization of energy, raw materials and other input goods & 0.8 \\
\hline Market share (\%) & 1.6 & Investment in the environment & 5.7 \\
\hline Relative market share & 0.8 & Description of community involvement & 3.3 \\
\hline Market share, breakdown by country/segment/product & 4.1 & Information on corporate social responsibility and objective & 4.9 \\
\hline Repurchase & 0.8 & Description of employee contracts/contractual issues & 0.8 \\
\hline
\end{tabular}

\section{References}

Adrem, A. (1999). Essays on disclosure practices in Sweden: Causes and effects (Doctoral dissertation, Lund Studies in Economics and Management, Vol. 51). Institute of Economic Research, University of Lund. 
Aggarwal, R., Leal, R., \& Hernandez, L. (1993). The aftermarket performance of initial public offerings in Latin America. Financial Manag., $22,42-53$.

Ahmad Zaluki, N. A., Campbell, K., \& Goodacre, A. (2009). Earnings management in Malaysian IPOs: The East Asian crisis, ownership control and post-IPO performance. Available from: http://ssrn.com/abstract $=963085$

AICPA. (1994). Improving business reporting - a customer focus: Meeting the information needs of investors and creditors. Comprehensive Report of the Special Committee on Financial Reporting (The Jenkins Report). New York.

Akhigbe, A., Johnston, J., \& Madura, J. (2006). Long-term industry performance following IPOs. Q. Rev. Econ. Finance, 46(4), 638-651.

Ali, A., Klasa, S., \& Yeung, E. (2009). The limitations of industry concentration measures constructed with compustat data: Implications for finance research. Rev. Financial Stud., 22(10), 3839-3871.

Barber, B. M., \& Lyon, J. D. (1997). Detecting long-run abnormal stock returns: The empirical power and specification of test statistics. J. Financial Econ., 43(3), 341-372

Beattie, V., \& Pratt, K. (2002). Voluntary annual report disclosures: What users want. Institute of Chartered Accountants of Scotland.

Beattie, V., McInnes, B., \& Fearnley, S. (2004). A methodology for analysing and evaluating narratives in annual reports: A comprehensive descriptive profile and metrics for disclosure quality attributes. Account. Forum, 28(3), 205-236.

Beatty, R. P., \& Ritter, J. R. (1986). Investment banking, reputation and the underpricing of initial public offerings. J. Financial Econ., 15, 213-232.

Bessler, W. \& Bittelmeyer, C. (2008). Patents and the performance of technology firms: Evidence from initial public offerings in Germany. Financial Mark Portf. Manag., 22(4), 323-356.

Bhabra, H. S., \& Pettway, R. H. (2003). IPO prospectus information and subsequent performance. Financial Rev., 38(3), 369-397.

Botosan, C. A. (1997). Disclosure level and the cost of equity capital. Account. Rev., 72(3), 323-349.

Bukh, P. N., Nielsen, C., Mouritsen, J., \& Gormsen, P. (2005). Disclosure of information on intellectual capital indicators in Danish IPO prospectuses. Account. Audit. Account. J., 18(6), 713-732.

Carter, R. B., Dark, F. H., \& Singh, A. K. (1998). Underwriter reputation, initial returns, and the longrun performance of IPO stocks. J. Finance, 53(1), 285-311.

Chang, C.-H. (2011). IPO underpricing: A social comparison perspective. Int. Rev. Econ. Finance, 20(3), 367-375.

Cho, J., \& Lee, J. (2013). The venture capital certification role in R\&D: Evidence from IPO underpricing in Korea. Pac. Basin Finance J., 23.(1), 83-108.

Clarkson, P. M., \& Merkley, J. (1994). Ex ante uncertainty and the underpricing of initial public offerings: Further Canadian evidence. Can. J. Adm. Sci., 11(2), $54-67$

Clatworthy, M., \& Jones, M. J. (2006). Differential patterns of textual characteristics and company performance in the chairman's statement. Account. Audit Account. J., 19(4), 493-511.

Coller, M., \& Yohn, T. L. (1997). Management forecasts and information asymmetry: An examination of bid-ask spreads. J. Account. Res., 35(2), 181-191.

Cooke, T. E. (1989). Voluntary corporate disclosure by Swedish companies. J. Int. Financial Manag. Account., 1(2), 171-195.

Cooke, T. E. (1991). An assessment of voluntary disclosure in the annual reports of Japanese corporations. Int. J. Account., 26(2), 174-189.

Cordazzo, M. (2007). Intangibles and Italian IPO prospectuses: A disclosure analysis. J. Intellect. Cap., 8(2), 288-305.

Cordazzo, M., \& Vergauwen, P. G. M. C. (2012). Intellectual capital disclosure in the UK biotechnology IPO prospectuses. J. Hum. Res. Costing Account., 16(1), 419.

Dawson, S. M., \& Hiraki, T. (1985). Selling unseasoned new shares in Hong Kong and Japan, a test of primary market efficiency and underpricing. Hong Kong J. Bus. Manag., 3, 125-134.

Diamond, D., \& Verrecchia, R. (1991). Disclosure, liquidity and the cost of equity capital. J. Finance, 46(4), 1325-1360.

Eberhart, A. C., Maxwell, W. F., \& Siddique, A. R. (2004). An examination of long-term abnormal stock returns and operating performance following R\&D increases. J. Finance, 59(2), 623-650.

Eccles, R., \& Mavrinac, S. (1995). Improving the corporate disclosure process. Sloan Manag. Rev., 36(4), 11-25.

Eckstein, C. (2004). The measurement and recognition of intangible assets: Then and now. Account. Forum, 28(2), 139-158.

El-Tawy, N., \& Tollington, T. (2013). Some thoughts on the recognition of assets, notably in respect of intangible assets. Account Forum, 37(1), 67-80.

Faulkner, T. (1996). Applying options thinking to R\&D valuation. Res. Technol. Manag., 39(3), 50-56.

Gosman, M., Kelly, P. M., Olsson, P., \& Warfield, T. (2004). The profitability and pricing of major customers. Rev. Account. Stud., 9(1), 117-139.

Gray, S. J., Meek, G. K., \& Roberts, C. B. (1995). International capital market pressure and voluntary annual report disclosures by U.S. and U.K. multinationals. J. Int. Financial Manag. Account., 6(1), 43-68.

Guo, R., Lev, B., \& Zhou, N. (2004). Competitive costs of disclosure by biotech IPOs. J. Account. Res., 42(2), 319.

Guthrie, J., \& Petty, R. (2000). Intellectual capital: Australian annual reporting evidence. J. Intellect. Cap., 1(3), 241-251.

Hackston, D., \& Milne, M. J. (1996). Some determinants of social and environmental disclosures in New Zealand companies. Account. Audit. Account. J., 9(1), 77-108.

Harris, M. S. (1998). The association between competition and managers' business segment reporting decisions. J. Account. Res., 36(1), 111-128.

Healy, P. M. \& Palepu, K. G. (2001). Information asymmetry, corporate disclosure, and the capital markets: A review of the empirical disclosure literature. J. Account. Econ., 31(1-3), 405-440.

Hirschey, M., \& Richardson, V. J. (2004). Are scientific indicators of patent quality useful to investors? J. Empir. Finance, 11(1), 91-107.
C., \& Dreher, A. (2013). Do differences in institutional and legal environments explain cross-country variations in IPO underpricing? Appl. Econ., 45(4), 435-454.

Hossain, M., Tan, M. L., \& Adams, C. (1994). Voluntary disclosure in an emerging capital market: Some empirical evidence from companies listed on the Kuala Lumpur stock exchange. Int. J. Account., 29(4), 334-351.

IIRC. (2012). Draft framework outline, by the International Integrated Reporting Council. http://www.theiirc.org/wp-content/uploads/2012/07/DraftFramework-Outline.pdf Accessed 16.11.12

Inchausti, B. (1997). The influence of company characteristics and accounting regulation on information disclosed by Spanish firms. Eur. Account. Rev., 6(1), $45-68$.

Jenkinson, T., \& Ljungquist, A. (2001). Going public: The theory and evidence of how companies raise equity finance (2nd ed.). Oxford: Oxford University Press. Jain, B. A., \& Kini, O. (1994). The post-issue operating performance of IPO firms. J. Finance, 49, 1699-1726.

Jain, B. A., \& Kini, O. (1999). The life cycle of initial public offering firms. J. Bus. Finance Account., 26(9\&10), $1280-1307$. Jain, B. A., \& Kini, O. (2000). Does the presence of venture capitalists improve the survival profile of IPO firms? J. Bus. Finance Account., 27(9-10), 1139-1176. Jog, V., \& McConomy, B. J. (2003). Voluntary disclosure of management earnings forecasts in IPO prospectuses. J. Bus. Finance Account., 30(1/2), $125-167$.

Johanson, U., Koga, C., Skoog, M., \& Henningsson, J. (2006). The Japanese Government's intellectual capital reporting guideline: What are the challenges for firms and capital market agents? J. Intellect. Cap., 7(4), 474-491.

Jones, M. J. (1994). A comment to contextualise performance and readability: A comparison of annual reports of profitable and unprofitable corporations. J. Bus. Commun., 31(3), 225-230.

Joshi, M., Singh Ubha, D., \& Sidhu, J. (2012). Intellectual capital disclosures by Indian and Australian information technology companies: A comparative analysis. J. Intellect. Cap., 13(4), 582-598.

Kao, J. L., Wu, D., \& Yang, Z. (2009). Regulations, earnings management, and post-IPO performance: The Chinese evidence. J. Bank. Finance, 33(1), 63-76.

Kim, B. J., Krinsky, I., \& Lee, J. (1995). The aftermarket performance of initial public offerings. Pac. Basin J., 3, 429-448.

Kothari, S. P., \& Warner, J. B. (1997). Measuring long-horizon security price performance. J. Financial Econ., 43(3), 301-340.

Khurshed, A., Mudambi, R. M., \& Goergen, M. (1999). On the long run performance of IPOs: The effect of pre-IPO management decisions. University of Reading, Economics \& Management Decision, Paper No. XII-401.

Kutsuna, K., Okamura, H., \& Cowling, M. (2002). Ownership structure pre- and post-IPOs and the operating performance of JASDAQ companies. Pac. Basin Finance J., 10(2), 163-181.

Kutsuna, K., Smith, J. K., \& Smith, R. (2009). Public information, IPO price formation, and long-run returns: Japanese evidence. J. Finance, 64(1), 505-546.

Kutsuna, K., \& Smith, R. (2004). Why does book building drive out auction methods of IPO issuance? Evidence from Japan. Rev. Financ. Stud., 17(4), 1129-1166.

La Rosa, F., \& Liberatore, G. (2014). Biopharmaceutical and chemical firms' R\&D disclosure, and cost of equity: The impact of the regulatory regime. Eur. Manag. J., 32(5), 806-820

Lee, P., Taylor, S., \& Walter, T. (1994). Australian IPO pricing in the short and long-run. University of Sydney. Mimeo.

Leuz, C., \& Verrechia, R. E. (2000). The economic consequence of increased disclosure. J. Account. Res., 38, 91-135.

Lin, L. S., Huang, I. C., Du, P. L., \& Lin, T. F. (2012). Human capital disclosure and organizational performance: The moderating effects of knowledge intensity and organizational size. Manag. Decis., 50(10), 1790-1799. 
Loughran, T., \& Ritter, J. R. (2004). Why has IPO underpricing increased over time? Financial Manag., 33(3), 5-37.

Loughran, T., Ritter, J. R., \& Rydqvist, K. (1994). International public offerings: International insights. Pac. Basin Finance J., 2, $165-200$.

Marston, C. L., \& Shrives, P. J. (1991). The use of disclosure indices in accounting research: A review article. Br. Account. Rev., 23(3), 195-210.

Meek, G. K., Roberts, C. B., \& Gray,S. J. (1995). Factors influencing voluntary annual report disclosures by U.S. and U.K. and continental European multinational corporations. J. Int. Bus. Stud., 26(3), 555-572.

Megginson, W., \& Weiss, K. A. (1991). Venture capitalists certification in initial public offerings. J. Finance, 46(3), 873-903.

Michaely, R., \& Shaw, W. H. (1994). The pricing of initial public offerings: Tests of adverse selection and signaling theories. Rev. Financial Stud., 7(2), 279-

319. Mouritsen, J., Bukh, P. N., Flagstad, K., Thorbjørnsen, S., Johansen, M. R., Kotnis, S., et al. (2003). Intellectual capital statements - The new guideline.

Copenhagen:

Danish Ministry of Science, Technology and Innovation.

Mouritsen, J., \& Larsen, H. T. (2005). The 2nd wave of knowledge management: The management control of knowledge resources through intellectual capital information. Manag. Account. Res., 16(3), 371-394.

Murthy, V., \& Mouritsen, J. (2011). The performance of intellectual capital: Mobilising relationships between intellectual and financial capital in a bank. Account. Audit. Account. J., 24(5), 622-646.

Nagata, K., \& Rhee, S. G. (2009). Ownership, control and underpricing in Initial Public Offerings: Evidence from Japan, working paper from Tokyo Institute of Technology. http://ssrn.com/abstract=1460592 Accessed 11.10.14

Pettway, R. H., \& Kaneko, T. (1996). The effects of removing price limits and introducing auctions upon short-term IPO returns: The case of Japanese IPOs. Pac. Basin Finance J., 4(2-3), 241-258.

Pettway, R. H., Thosar, S., \& Walker, S. (2008). Auctions versus book-built IPOs in Japan: A comparison of aftermarket volatility. Pac. Basin Finance J., 16(3), $224-235$.

Rajan, R., \& Servaes, H. (1997). Analyst following of initial public offerings. J. Finance, 52(2), 507-529.

Ranft, A., \& Lord, M. (2002). Acquiring new technologies and capabilities: A grounded model of acquisition implementation. Organ. Sci., 13(4), 420-441.

Rashid, A. A., Ibrahim, M. K., Othman, R., \& See, K. F. (2012). IC disclosures in IPO prospectuses: Evidence from Malaysia. J. Intellect. Cap., 13(1), 57-80.

Rimmel, G. (2003). Human resource disclosures - A comparative study of annual reporting practice about information. In Providers and users in two corporations. Göteborg: BAS Publishing House.

Rimmel, G. (2004). Perceptions of human resource disclosures - Evidence from annual report users of two corporations. Financial Report. Regul. Gov., 3(1), $65-94$.

Rimmel, G., Nielsen, C., \& Yosano, T. (2009). Intellectual capital disclosures in Japanese IPO prospectuses. J. Hum. Res. Costing Account., 13(4), 316-337.

Richardson, A. J., \& Welker, M. (2001). Social disclosure, financial disclosure and the cost of equity capital. Account. Organ. Soc., 26(7), 597-616.

Ritter, J. R. (1991). The long-run performance of initial public offerings. J. Finance, 46, 3-27.

Sakakibara, S., Hansson, B., Yosano, T., \& Kozumi, H. (2010). Analysts' perceptions of intellectual capital information. Aust. Account. Rev., 20(3), 274-285.

Schrand, C., \& Verrechia, R. E. (2004). Disclosure choice and cost of capital: Evidence from underpricing in initial public offerings. Philadelphia, PA: The Wharton School, University of Pennsylvania. Working paper.

See, K. F., \& Rashid, A. A. (2012). Determinants of non-disclosure of intellectual capital information in Malaysian IPO prospectuses. Int. J. Econ. Finance, 3(5), $178-186$.

Singh, I., \& Van der Zahn, J. L. W. M. (2007). Does intellectual capital disclosure reduce an IPOs cost of capital? The case of underpricing. J. Intellect. Cap., $8(3), 494-516$

Singh, I., \& Van der Zahn, J. L. W. M. (2008). Determinants of intellectual capital disclosure in prospectuses of initial public offerings. Account. Bus. Res., 38(5), 409-431.

Spero, L. L. (1979). The extent and causes of voluntary disclosure of financial information in three European countries: An explorative study. Boston, USA: Harvard University Press.

Ström, N. (2006). Essays on information disclosure: Content, consequence and relevance (PhD dissertation). Sweden: Department of Business Studies, Uppsala University.

Sveiby, K. E. (1997). The new organizational wealth: Managing and measuring knowledge-based assets. San Francisco: Berrett Koehler.

Thomadakis, S., Nounis, C., \& Gounopoulos, D. (2012). Long-term performance of Greek IPOs. Eur. Financial Manag., 18(1), 117-141.

Tokyo Stock Exchange. (2012). Guideline of the criteria for listing to the Tokyo Stock Exchange. http:// tse-gr.info/rule/JPH19TE8302061101002.html Accessed 01.04 .12

Too, S. W., \& Somasundaram, N. R. (2011). Determinants of corporate disclosure on intellectual capital in Malaysian IPO prospectuses. Int. J. Learn. Intellect. Cap., 8(4), 418-435

Unerman, J. (2000). Methodological issues: Reflections on quantification in corporate social reporting content analysis. Account. Audit. Account. J., 13(5), 667680.

Vance, D. E., \& Mascarenhas, B. (2014). Are there simple indicators as to which IPOs outperform the market over the long term? Br. J. Econ. Manag. Trade, 4(2), 183-196.

Verrecchia, R. E. (2001). Essays on disclosure. J. Account. Econ., 32, 97-180.

Wallace, R. S. O., Naser, K., \& Mora, A. (1994). The relationship between the comprehensiveness of corporate annual reports and firm characteristics in Spain. Account. Bus. Res., 25(97), 41-53.

Wang, C. (2004). Ownership and operating performance of Chinese IPOs. J. Bank. Finance, 29, 1835-1856.

Welker, M. (1995). Disclosure policy, information asymmetry and liquidity in equity markets. Contemp. Account. Res., 11(2), 801-827.

Xia, N., Junyan, S., \& Pei, G. (2013). Empirical study on initial public offering (IPO) underpricing and long-run performance: Evidence from China's A-share market. Afr. J. Bus. Manag., 7(11), 852-861.

$\mathrm{Xu}, \mathrm{Z}$., \& Xu, L. (2012). IPO valuation of entrepreneurial firms in China's new growth enterprise market: An examination of board composition, top management team's ownership and human capital. J. Chin. Entrep., 4(3), 206-220.

Yamamoto, T. (2009). The listing market choice and the IPO underpricing: An empirical approach, working paper from Iwate Prefectural University. Retrieved from: http://ssrn.com/abstract $=1340407$

Yi, A., \& Davey, H. (2010). Intellectual capital disclosure in Chinese (mainland) companies. J. Intellect. Cap., 11(3), 326-347.

Zéghal, D., \& Maaloul, A. (2011). The accounting treatment of intangibles - A critical review of the literature. Account. Forum, 35(4), 262-274. 